\title{
Establishment of the Microflora and Anaerobic Fungi in the Rumen of Lambs
}

\author{
By GÉRARD FONTY, ${ }^{1,3 *}$ PHILIPPE GOUET, ${ }^{1}$ JEAN-PIERRE JOUANY ${ }^{2}$ \\ AND JEAN SENAUD ${ }^{3}$ \\ ${ }^{1,2}$ Laboratoire de Microbiologie ${ }^{1}$ and Laboratoire de la Digestion ${ }^{2}$, INRA Centre de Recherches \\ de Clermont-Ferrand Theix, Saint-Genes Champanelle, 63122 Ceyrat, France \\ ${ }^{3}$ Laboratoire de Biologie Comparée des Protistes, CNRS, UA, 138 Université de Clermont II, \\ 63170 Aubière, France
}

(Received 25 September 1986; revised 9 January 1987)

\begin{abstract}
The establishment of different bacterial populations and fungi in the rumen was investigated in lambs reared under different conditions of diet and management. The rumen was rapidly colonized by an abundant microflora after birth. By day 2 strictly anaerobic bacteria predominated $\left(10^{9}\right.$ c.f.u. $\left.\mathrm{ml}^{-1}\right)$; their population increased slightly during the first week of life and again when the animals began to ingest solid feed ( 3 weeks). The composition of the microflora in the 2-10-d-old lambs was quite different from that of adult sheep. The aerobic and facultatively anaerobic bacterial count was 10-100-fold lower than the strictly anaerobic count during the first week, and decreased steadily afterwards. In flock-reared lambs, cellulolytic and methanogenic bacteria appeared very early after birth (3-4 d). At the end of the first week the population of these bacteria reached a level close to that generally observed in a mature rumen. The cellulolytic bacteria were also able to survive in the rumen of lambs fed cow's milk exclusively. Anaerobic fungi appeared later (8-10 d). They were present in all lambs studied until 3 weeks of age, and then disappeared in most of them when a solid diet was given.
\end{abstract}

\section{INTRODUCTION}

Most studies on rumen microbiology have focused on the mature animal, and little work has been done on the rumen of the young preruminant. In the calf, only Bryant et al. (1958), Bryant \& Small (1960), and Jayne-Williams (1979) have studied the establishment of strictly anaerobic bacteria while other workers have restricted themselves to direct counts of bacteria by light microscopy (Pounden \& Hibbs, $1948 a, b$ ) or have simply concentrated on a few easily grown bacterial groups (Mackay \& Oxford, 1954; Mann \& Oxford, 1954, 1955; Lengemann \& Allen, 1959; Ziolecki \& Briggs, 1961). In the lamb only the epimural flora (bacteria attached to the rumen wall) has been studied (Mueller et al., 1984a, b).

Studies on laboratory animals (Brunel \& Gouet, 1982; Gouet \& Fonty, 1979; Morishita \& Miyaki, 1979; Raibaud et al., 1966a,b) have shown that the digestive microflora appears in a clearly defined sequence; the establishment of the digestive ecosystem is ordered and progressive. A descriptive study of the chronological appearance of the main microbial species in the rumen should enable the mechanisms involved in the establishment of the rumen ecosystem to be investigated, which may help to solve some of the problems posed by weaning.

Despite the importance of the cellulolytic and methanogenic bacteria, no precise determination has been made of the times at which they appear. The part played by fungi in the degradation of plant cell walls can no longer be overlooked, and yet their presence in the young preruminant has yet to be investigated. It would also be interesting to know how the microflora is transmitted between mature and newborn animals. Some species can be transmitted without 
direct contact (Bryant \& Small, 1960; Mann, 1963) but there is no evidence to suggest that this is the case for all species, and in particular for the cellulolytic bacteria, which are extremely oxygen sensitive.

The objectives of this study were to follow, from birth, the sequential establishment of strictly anaerobic, aerobic and facultatively anaerobic bacteria, cellulolytic and methanogenic bacteria, and anaerobic fungi in the rumen of lambs reared in farm conditions (in a flock or with their mother). The influence of milk diets and the isolation of lambs shortly after birth, which are customary in certain modern rearing methods were investigated for their effects on the establishment of the cellulolytic flora.

\section{METHODS}

Animals. The lambs used in this study were divided into five groups. The conditions of management and the objectives of the study for each group are summarized in Table 1. The lambs in groups I, II and III were reared in farm conditions of husbandry; those in groups IV and V were bottle fed with milk only.

Group I consisted of 24 lambs, flock-reared with their mother. From birth they had access ad libitum to a meadow hay and to a pelleted concentrate composed of $(\%, w / w)$ : maize grain, 80 ; peanut and soybean meal, 15 ; vitamin and mineral supplement, 5.

Group II comprised three sets of two lambs reared in boxes with their mother until $42 \mathrm{~d}$ old and then weaned and separated from their mother. From the second week of life they had access ad libitum to a complete pelleted feed containing $(\%, w / w)$ : meadow hay, 30; roughly chopped lucerne, 5 ; dried beet pulp, 19.3; barley grain, 15 ; oat grain, 4 ; peanut meal, 21.7 ; glucose, 3.3 ; molasses, 1 ; vitamin and mineral supplement, 0.7 .

Group III comprised 11 lambs flock-reared with their mother. At 3 weeks of age they received a meadow hay and a growth diet ad libitum composed of $(\%, w / w)$ : barley grain, 18; maize grain, 27; wheat grain, 10; dried beet pulp, 20; dried lucerne, 2 ; rapeseed meal, 12.4 ; soybean meal, 5 ; molasses, 2 ; urea, 0.35 ; calcium carbonate, 0.75 ; ammonium chloride, 1 ; sodium chloride, 0.5 ; mineral supplement, 1 . This group was formed to make counts of methanogenic bacteria and anaerobic fungi which were not performed for groups I and II.

In group IV, four lambs were separated from their mother after birth and bottle fed ad libitum with cow's milk twice a day. They were reared in boxes with a concrete floor and no straw bedding to ensure that there was no ingestion of solid feed. During the first 4 weeks of life they were left for a few hours a day with mature sheep, which were also in boxes without straw bedding.

In group V, 18 lambs were separated from their mother $24 \mathrm{~h}$ after birth. They were kept in three lots of six boxes, each lot corresponding to a different period of lambing. The boxes were metallic, containing no bedding, in a sheepfold isolated from other ruminants. The lambs were fed twice daily ad libitum with a commercial milkreplacer diet containing $(\%, w / w)$ : crude protein, 22; fat, 24; cellulose, 1 ; minerals, 8; plus spiramycin and bacitracin, 20 and 60 p.p.m. respectively. Rumen contents were sampled up to day 42 for two sets of lambs and up to day 56 for the third. Two lambs from this last set were then placed with those of group IV but continued to receive the milk-replacer diet.

Sampling of rumen contents. Samples of rumen contents were withdrawn by stomach tube from all lambs except for four animals in group II which were fitted with a permanent rumen cannula at $2 \mathrm{~d}$ of age. The lambs were sampled before the morning feed.

Bacteriological techniques and culture media. Samples of rumen contents were withdrawn into screw-capped tubes. Dilution series were prepared under $\mathrm{O}_{2}$-free $\mathrm{CO}_{2}$ by the anaerobic method of Bryant (1972) using the mineral solution of Bryant \& Burkey (1953).

Total viable counts of bacteria were determined using medium CCA (Allison et al., 1979) and medium M2 (Hobson, 1969). The media were dispensed into $16 \times 150 \mathrm{~mm}$ Hungate tubes sealed with butyl rubber stoppers (Bellco). Cellulolytic bacteria were counted in the RGCA medium of Bryant \& Burkey (1953) without agar, in which glucose and cellobiose were replaced by cellulose as a strip of filter paper (Whatman no. 1). Methanogenic bacteria were counted in the medium of Smith \& Hungate (1958) under $\mathrm{H}_{2} / \mathrm{CO}_{2}(80: 20, \mathrm{v} / \mathrm{v})$. The presence of methanogenic bacteria in each tube was determined by $\mathrm{GC}$ analysis of $\mathrm{CH}_{4}$ production.

Three sets of roll tubes or liquid culture were made from each dilution series. In roll tubes, the viable count was taken as the mean of the three roll tube counts at the appropriate dilution. The counts of cellulolytic and methanogenic bacteria were taken as the most probable number. Roll tubes were incubated for $7 \mathrm{~d}$ at $39^{\circ} \mathrm{C}$, and media for cellulolytic and methanogenic bacteria for $21 \mathrm{~d}$ at $39^{\circ} \mathrm{C}$.

Counts of aerobic and facultatively anaerobic bacteria were made in Petri dishes on the following media: medium C for total counts (Raibaud et al., 1966a), desoxycholate agar medium (DCA) (Difco) for Escherichia coli, KF Streptococcus medium (KF) (Difco) for streptococci, Rogosa SL Agar medium (Difco) for lactobacilli. These media were incubated for $2 \mathrm{~d}$ at $39^{\circ} \mathrm{C}$.

The presence of anaerobic fungi was determined in roll tubes by the method of Joblin (1981). Two tubes were inoculated for each dilution. 
Table 1. Groups of lambs: conditions of management, period of sampling, objectives of the study and microbiological counts

\begin{tabular}{|c|c|c|c|c|c|}
\hline Group ... & I & II & III & IV & v \\
\hline $\begin{array}{l}\text { No. of lambs } \\
\text { Environmental } \\
\text { conditions }\end{array}$ & $\begin{array}{c}24 \\
\text { Flock-reared }\end{array}$ & $\begin{array}{c}6 \\
\text { Reared in boxes } \\
\text { with their dams }\end{array}$ & $\stackrel{11}{\text { Flock-reared }}$ & $\begin{array}{l}4 \\
\text { Reared in boxes; } \\
\text { in contact with } \\
\text { other sheep }\end{array}$ & $\begin{array}{l}18 \\
\text { Isolated; no contact } \\
\text { with other } \\
\text { ruminants }\end{array}$ \\
\hline Feed & $\begin{array}{l}\text { Milk* + solid } \\
\text { feed from birth }\end{array}$ & $\begin{array}{l}\text { Milk* + solid } \\
\text { feed from week } 2\end{array}$ & $\begin{array}{l}\text { Milk + solid } \\
\text { feed from week } 3\end{array}$ & Cow's milk & Milk replacer \\
\hline $\begin{array}{l}\text { Period of } \\
\text { sampling }\end{array}$ & $2-18 d$ & $2-98 d$ & $2-12 d$ & $7-110 d$ & $7-56 d$ \\
\hline $\begin{array}{l}\text { Microbiological } \\
\text { counts }\end{array}$ & $\begin{array}{l}\text { Strictly anaerobic } \\
\text { Aerobic and facu } \\
\text { bacteria } \\
\text { Cellulolytic bacte }\end{array}$ & $\begin{array}{l}\text { sacteria } \\
\text { atively anaerobic }\end{array}$ & $\begin{array}{l}\text { Methanogenic } \\
\text { bacteria } \\
\text { Fungi }\end{array}$ & $\begin{array}{l}\text { Cellulolytic } \\
\text { bacteria }\end{array}$ & $\begin{array}{l}\text { Cellulolytic } \\
\text { bacteria }\end{array}$ \\
\hline $\begin{array}{l}\text { Objectives of } \\
\text { the study }\end{array}$ & \multicolumn{3}{|c|}{$\begin{array}{l}\text { Establishment of microbial populations in the rumen of } \\
\text { lambs reared in farm conditions }\end{array}$} & $\begin{array}{l}\text { Establishment of } \\
\text { the cellulolytic } \\
\text { flora in lambs } \\
\text { fed only with } \\
\text { milk }\end{array}$ & $\begin{array}{l}\text { Influence of contact } \\
\text { between the } \\
\text { newborn and its } \\
\text { mother on the } \\
\text { establishment of } \\
\text { cellulolytic } \\
\text { bacteria }\end{array}$ \\
\hline
\end{tabular}

Bacterial identification. One hundred and seventy strains were isolated from M2 and CCA media inoculated with the $10^{-7}, 10^{-8}$ and $10^{-9}$ dilutions of the samples taken from the lambs in groups I and II when they were 2,4 and $7 \mathrm{~d}$ old. The strains were grown either in medium RGCA (Bryant \& Burkey, 1953) to which starch was added at $0.4 \%$, or in medium M2. Twenty strains were isolated from KF medium and grown in medium C (Raibaud et al., $1966 a$ ). They were purified by streaking on Petri dishes in an anaerobic glove box $\left(\mathrm{CO}_{2} / \mathrm{H}_{2}, 98: 2, \mathrm{v} / \mathrm{v}\right.$ ) (Aranki \& Freter, 1972). They were identified according to the following criteria: morphology, motility, Gram stain, oxygen sensitivity, the end-products of the fermentation of glucose (volatile fatty acids, ethanol, lactic acid), the production of acid from different carbohydrate substrates (D-glucose, D-fructose, D-galactose, D-xylose, Larabinose, raffinose, D-cellobiose, saccharose, lactose, maltose, starch, xylan, pectin, cellulose, mannitol, glycerol, sodium lactate), hydrolysis of gelatin and production of $\mathrm{H}_{2} \mathrm{~S}$. The culture media used were those described by Dehority (1963). The end-products of fermentation were analysed by GC (Jouany, 1982). The production of acid from the carbon sources other than cellulose was determined by a technique similar to that of Wilkins et al. (1975), which uses titration plates (Flow plates no. 76:033.05) consisting of 24 wells of $3 \mathrm{ml}$, in an anaerobic glove box. Culture transfer was done with a Denley A400 automatic multipoint inoculator. Readings were taken after 1 week of incubation at $39^{\circ} \mathrm{C}$ by measuring the $\mathrm{pH}$ in each well. Two wells were not inoculated and served as controls. The substrate was considered to be fermented when the $\mathrm{pH}$ was lower by at least 0.3 units than the controls (Dehority, 1963). The degradation of cellulose, added to the culture medium in the form of a strip of filter paper, was observed in the Hungate tubes. The different strains were assigned to genera and species on the basis of criteria described in standard texts (Holdeman \& Moore, 1972; Buchanan \& Gibbons, 1974).

Identification of fungi. The fungi were identified essentially by their morphology, according to the criteria of Orpin (1981).

\section{RESULTS}

Development of the total anaerobic, aerobic and facultatively anaerobic flora

In the lambs of group I (Fig. 1) and group II (Fig. 2) the rumen was rapidly colonized after birth by an abundant bacterial population. From day 2 , the counts of strict anaerobes reached $10^{9}$ c.f.u. $\mathrm{ml}^{-1}$. The number increased slightly during the first week of life and again when the animals began to ingest solid feed (group II, Fig. 2). Figs 1 and 2 show only the counts obtained in CCA medium, which were 1.5 to 2 times greater than those in M2 medium.

The total aerobic and facultatively anaerobic bacterial counts during the first week of life were 10-100 times lower than the strict anaerobic microflora counts (Figs 1 and 2). Thereafter they decreased steadily. Streptococci and $E$. coli were the main components of this microflora. Lactobacilli were present only in two lambs from group I and one from group II; their population ranged from $3 \times 10^{4}$ to $5 \times 10^{4}$ c.f.u. $\mathrm{ml}^{-1}$. 


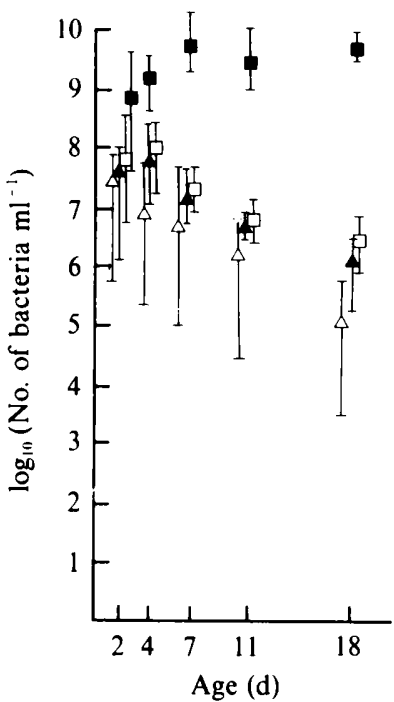

Fig. 1

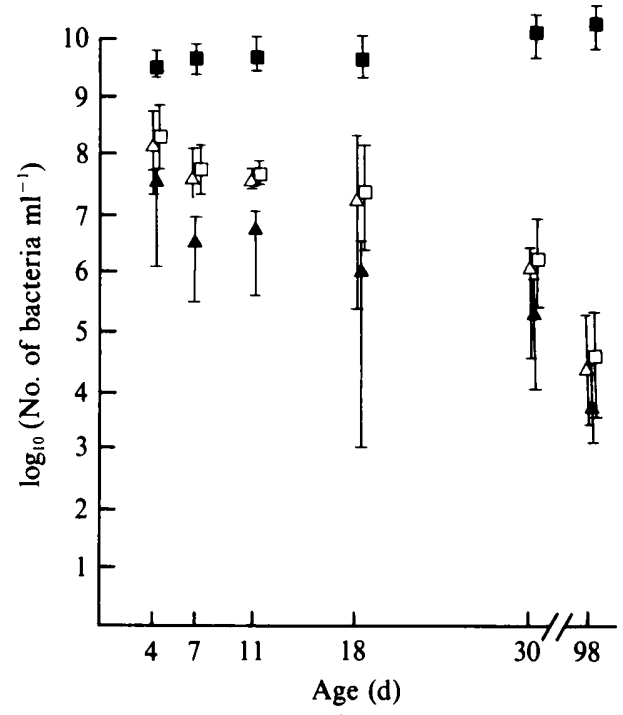

Fig. 2

Fig. 1. Counts of bacteria (ml rumen contents) ${ }^{-1}$ in the rumen of seven lambs from group 1. $\square$, Total strict anaerobes; $\square$, facultative anaerobes; $\Delta$, streptococci; $\triangle, E$. coli. The bar shows the range between the highest and the lowest counts and the symbol the mean value.

Fig. 2. Counts of bacteria ( $\mathrm{ml}$ rumen contents) ${ }^{-1}$ in the rumen of four lambs from group II. $\mathbf{0}$, Total strict anaerobes; $\square$, facultative anaerobes; $\Delta$, streptococci; $\triangle, E$. coli. The bar shows the range between the highest and the lowest counts and the symbol the mean value.

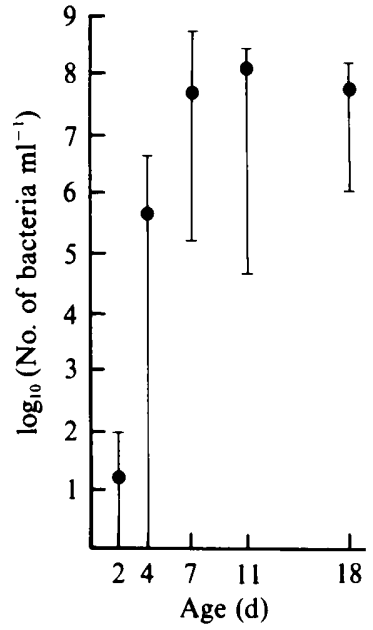

Fig. 3

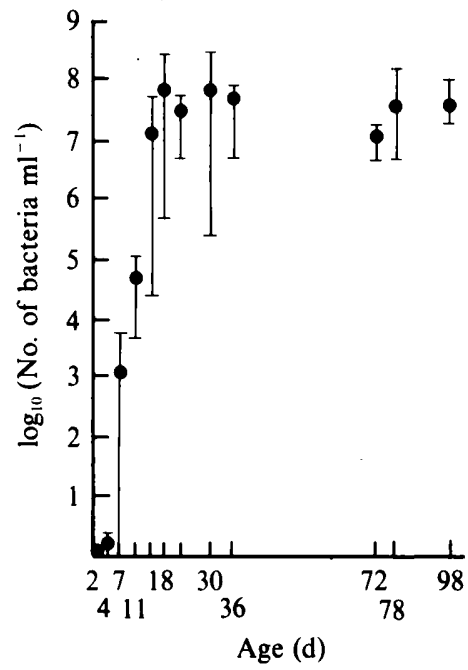

Fig. 4

Fig. 3. Counts of cellulolytic bacteria ( $\mathrm{ml}$ rumen contents) ${ }^{-1}$ in the rumen of 24 lambs from group I. The bar shows the range between the highest and the lowest counts and the symbol the mean value.

Fig. 4. Counts of cellulolytic bacteria ( $\mathrm{ml}$ rumen contents) ${ }^{-1}$ in the rumen of six lambs from group II. The bar shows the range between the highest and the lowest counts and the symbol the mean value.

\section{Development of the cellulolytic flora}

In the lambs of groups I and II, which were reared with their mothers, cellulolytic bacteria appeared in the rumen very early (Figs 3 and 4). They were present in 19 of the 24 lambs studied in group I from day 4 , but the counts were highly variable, from $10^{2}$ to $10^{7}$ bacteria $\mathrm{ml}^{-1}$. By the 


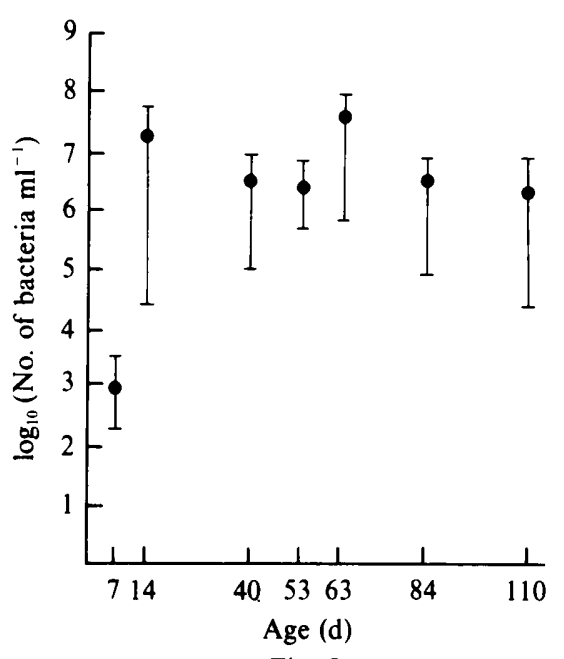

Fig. 5

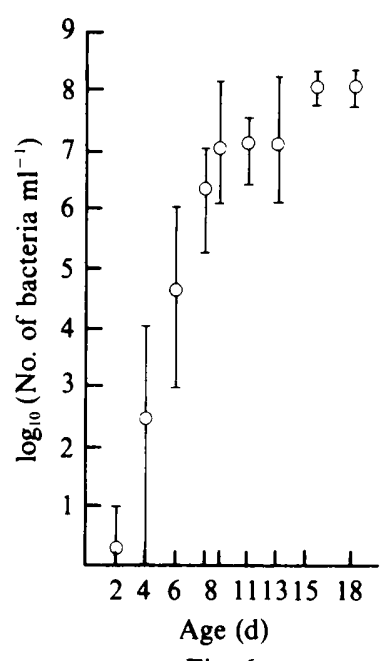

Fig. 6

Fig. 5. Counts of cellulolytic bacteria ( $\mathrm{ml}$ rumen contents) $)^{-1}$ in the rumen of four lambs from group IV. The bar shows the range between the highest and the lowest counts and the symbol the mean value.

Fig. 6. Counts of methanogenic bacteria (ml rumen contents) ${ }^{-1}$ in the rumen of lambs from group III. Five lambs were sampled at days 2,6,9 and 13, and six lambs at days 4, 8, 11 and 15 . The bar shows the range between the highest and the lowest counts and the symbol the mean value.

end of the first week these bacteria were found in all the animals and the variability had decreased. The population was already numerous, close to that generally found in a mature rumen. Cellulolytic bacteria were present in the six lambs of group II at day 7 but their establishment was slower and more progressive than in the animals of group I. At day 4 they were present in only one lamb. Four of them were fitted with a rumen cannula at $2 \mathrm{~d}$ old, and this might explain the later appearance of this bacterial population.

In the lambs of group IV (Fig. 5), fed cow's milk by bottle but reared in contact with adult ruminants, cellulolytic bacteria became established towards the end of the first week. The population remained stable throughout the experimental period despite the absence of solid feed. In the lambs of group V, reared in isolation, these bacteria did not occur. At day 56, two lambs from this group were put with those of group IV, which had been in contact with other lambs; cellulolytic bacteria became established in their rumen $5 \mathrm{~d}$ after the change of environment $\left(10^{3}-10^{4}\right.$ bacteria $\left.\mathrm{ml}^{-1}\right)$. Their number then increased to reach $10^{6}$ bacteria $\mathrm{ml}^{-1}$ $10 \mathrm{~d}$ later.

The cellulolytic species were not identified but microscopic observation of the residue of the strips of filter paper revealed the predominance of Ruminococcus in most of the lambs, irrespective of their age or group.

\section{Methanogenic bacteria}

Methanogens also became established soon after birth (Fig. 6). They were present in one lamb at day 2, in three others at day 4 and in all of them at the end of the first week. Their population increased thereafter to $10^{8} \mathrm{ml}^{-1}$.

\section{Anaerobic fungi}

Anaerobic fungi appeared in the rumen of two lambs on day 8 at counts of $10^{2}-10^{3}$ zoospores $\mathrm{ml}^{-1}$. They were present in all lambs between days 10 and 20. They then disappeared in 9 of the 11 lambs studied, after a growth diet was given (day 21). The population was composed essentially of organisms resembling Neocallimastix frontalis. Sphaeromonas communis was isolated from only two lambs. 
Table 2. Characteristics of the strains of bacteria isolated from the rumen of the 2-10-day old lambs in groups I and II

\begin{tabular}{|c|c|c|c|c|c|c|c|c|}
\hline Group & $\begin{array}{l}\text { Sub- } \\
\text { group }\end{array}$ & Morphology & $\begin{array}{l}\text { Gram } \\
\text { reaction }\end{array}$ & Motility & $\begin{array}{l}\text { Aerobic } \\
\text { growth }\end{array}$ & End-products* & Tentative identification & $\begin{array}{l}\text { No. of } \\
\text { isolates }\end{array}$ \\
\hline $\mathbf{A}$ & 1 & Rod & + & - & - & $\mathrm{P}, \mathrm{A}$ or $\mathrm{a},(\mathrm{L}$ or $\mathrm{l})$ & Propionibacterium acnes & 23 \\
\hline & 2 & $\operatorname{Rod}$ & + & - & - & P, L & Propionibacterium sp. & 8 \\
\hline B & 1 & Rod (+ spore) & $+(+1-)$ & - & - & $\mathrm{a}, \mathrm{L},(\mathrm{e})$ & Clostridium sp. & 17 \\
\hline & 2 & $\operatorname{Rod}(+$ spore) & + & - & - & $\mathbf{L}, \mathbf{P}, \mathbf{a}$ & Clostridium sp. & 4 \\
\hline & 3 & Rod (+ spore) & + & - & - & $\mathrm{L}, \mathrm{a}, \mathrm{b}$ & Clostridium chauvoei & 3 \\
\hline & 4 & Rod (+ spore) & + & - & - & $\mathrm{L}, \overrightarrow{\mathrm{A}}, \mathrm{e}$ & Clostridium ramosum & 4 \\
\hline C & 1 & Rod & - & - & - & $A, P$ or $p,(L$ or 1$)$ & Bacteroides sp. & 31 \\
\hline D & & Rod & - & - & - & $A, L$ or $\mathrm{l}, \mathrm{b}$ & Unidentified & 6 \\
\hline $\mathbf{E}$ & & Rod & - & - & - & $\mathrm{A}, \mathrm{l}, \mathrm{e}$ & Clostridium clostridioforme & 15 \\
\hline $\mathbf{F}$ & & Rod & + & - & - & L, a, (p) & Eubacterium sp. & 9 \\
\hline G & & Coccus & + & - & - & $A,(1)$ & Peptostreptococcus productus & 9 \\
\hline $\mathbf{H}$ & & Rod & + & - & - & $A,(\mathbf{L}, \mathrm{e})$ & Bifidobacterium adolescentis & 15 \\
\hline 1 & & $\begin{array}{r}\text { Rod (long) } \\
\text { filaments) }\end{array}$ & $+(+1-)$ & - & - & $\mathrm{A}, \mathrm{i}, \mathrm{e}$ & Lachnospira multiparus & 6 \\
\hline J & & Rod & + & - & - & $A, L, b,(e)$ & Unidentified & 8 \\
\hline $\mathbf{K}$ & & Coccus & + & - & + & L & $\begin{array}{l}\text { Streptococcus bovis, } \\
\text { Streptococcus sp. }\end{array}$ & 27 \\
\hline L & & $\operatorname{Rod}$ & + & - & + & L & Lactobacillus sp. & 5 \\
\hline
\end{tabular}

- A, a, acetate; P, p, propionate; B, b, butyrate; L, l, lactate; E, e, ethanol. Lower case indicates production of $<10 \mathrm{mM}$ product, upper case, production of $\geqslant 10 \mathrm{~mm}$ product; ( ), product not formed by all strains in the group.

\section{Identification of the predominant flora of the rumen of lambs less than $10 \mathrm{~d}$ old}

The 190 strains studied were classified into 12 groups on the basis of morphology, Gram stain and oxygen sensitivity (Table 2). Within each group, they were divided into subgroups according to the end-products of the fermentation of glucose. All the characteristics necessary for a complete identification were not studied, so for certain groups or subgroups it was not possible to give the name of the species, and for groups $\mathrm{D}$ and $\mathrm{J}$, not even the name of the genus (Table 2).

\section{DISCUSSION}

The microbial colonization of the rumen of lambs reared in farm conditions is characterized by the dominance of strictly anaerobic species very soon after birth $(2 \mathrm{~d})$ and by the early appearance (first week) of populations of cellulolytic and methanogenic bacteria, and anaerobic fungi, characteristic of the mature ruminant. The appearance of these populations is not dependent on the feed composition, since during this period the rumen has no functional activity. It contains only saliva, mucus and desquamated epithelial cells (Jayne-Williams, 1979; G. Fonty, unpublished observations). The milk ingested during suckling does not pass through the rumen because the oesophageal groove is closed by a reflex action, although a little may spill into the rumen, and therefore provide traces of nutrients for the microbial population. Furthermore, the consumption of solid feed does not generally begin until the end of the first or second week, as is shown by the observation of rumen contents. It was probably for these reasons that we did not observe any great difference in colonization between the lambs in groups I and II. Methanogenic bacteria and anaerobic fungi also became established during the same period, based on the results obtained with the lambs of group III, which were reared in similar farm conditions. Thus the colonization of the rumen is different from that of the digestive tract of most monogastric animals such as rats and mice (Ducluzeau, 1983), in which strictly anaerobic species are not found until weaning, except in rabbits (Gouet \& Fonty, 1979).

Although a large population of strictly anaerobic bacteria colonizes the rumen of the newborn lamb, the dominant species are different from those found in the mature animal. The genera Propionibacterium, Clostridium, Peptostreptococcus and Bifidobacterium, which we 
isolated in large numbers, are only rarely found as predominant members of the flora of the mature animal. Large numbers of Clostridium are also characteristic of the microflora of the very young lamb, while in the adult ruminant the microflora is composed essentially of non-sporulating species. In contrast, certain typical species of the adult were not found in the young lambs, either because they were absent or because they were present in low numbers and were not detected by the bacteriological methods we used. Similarly, microscopic examination of the rumen contents indicated that large bacteria like Quin's oval or Oscillospira were absent. Qualitatively, the composition of the dominant microflora of the rumen changes as the animal matures, in particular at weaning, as reported by Bryant et al. (1958) in the calf. It is clear, therefore, that at this period the composition of this flora is closely dependent on the feed composition.

As previously observed in calves by Bryant $e t$ al. (1958), Bryant \& Small (1960) and JayneWilliams (1979), the aerobic and facultatively anaerobic microflora in our lambs reared in normal conditions of husbandry declined rapidly with the age of the animals. This decrease may be due to the low growth yield of facultatively anaerobic bacteria, which is often only half that of strictly anaerobic bacteria (Hespell \& Bryant, 1979).

While the microflora of the rumen contents of the lambs is different from that of the mature animal, it is very similar to the flora adhering to the rumen wall. Thus, the genera Propionibacterium and Eubacterium, which we frequently isolated, were found by Cheng et al. (1981) on the rumen wall in almost all the sites studied. Similarly, the strains of Bacteroides that we isolated produced large quantities of lactic acid and are not typical of the strains generally found in the mature animal, but they are similar to those which adhere to the rumen wall and which were identified by Dehority \& Grubb (1981) and Mueller et al. $(1984 a, b)$.

Contrary to what is generally believed, the cellulolytic bacteria did not first occur in the rumen at weaning but were present in large numbers before the ingestion of solid feed. Bryant $e t$ al. (1958) also observed cellulolytic bacteria in calves at the end of the first week of life. These bacteria do not require plant cell-wall material to support their growth since they were found in relatively high numbers in lambs fed exclusively with milk (group IV). In such lambs the rumen contains few or no energy substrates (cellulose or its hydrolysis products) that might be used by these species. In such a biotype, cellulolytic bacteria are dependent for their nutritional requirements on other, non-cellulolytic, species, as shown in previous studies on gnotobiotic animals (Fonty et al., 1983). Contact between the newborn lamb and its mother or other adult ruminants during the first days of life was apparently necessary for their establishment. The lambs in group $\mathrm{V}$ were reared in isolation and the cellulolytic flora did not become established. This cannot be ascribed to the milk replacer, since when two of these lambs were placed in contact with those of group IV cellulolytic bacteria appeared in the rumen within 3 or $4 \mathrm{~d}$. It is possible, however, that in other experimental conditions not covered by our study, bedding may well act as a reservoir or transmission vector for cellulolytic species.

The appearance of anaerobic fungi towards the end of the first week of life was another new observation. These micro-organisms, which had previously only been found in mature animals on a roughage-rich diet (Bauchop, 1979; Orpin, 1984), must therefore be able to develop in the rumen before the ingestion of solid food. It would seem, however, that the composition of the diet is thereafter an important factor for their survival, since these fungi disappeared in almost all the lambs after the solid feed was given. However, this has yet to be confirmed. The influence of the feed composition clearly deserves further study. It is possible that other factors, in particular those relating to the physiology of the lambs, which were not investigated in our study, contributed to the disappearance of the fungi.

The results from this study, and previous work on the establishment of ciliate protozoa (Bryant et al., 1958; Eadie, 1962), thus show that the rumen ecosystem is quickly established after birth before the rumen itself becomes functional.

We would like to thank Anne Citron and Professor A. Breton (University of Clermont-Ferrand) for their contribution in the characterization of fungi, and Frédérique Bonnemoy for her skilled technical assistance. 


\section{REFERENCES}

Allison, M. J., Robinson, I. M., Bucklin, J. A. \& BoOTH, G. D. (1979). Characterization of bacterial populations from the pig gut based upon the energy sources used for growth. Applied and Environmental Microbiology 37, 1142-1151.

ARANKI, A. \& FrETER, R. (1972). Use of an anaerobic glove box for the cultivation of strictly anaerobic bacteria. American Journal of Clinical Nutrition 25, 1329-1334.

BAUCHOP, T. (1979). Rumen anaerobic fungi of cattle and sheep. Applied and Environmental Microbiology 38, $148-158$.

Brunel, A. \& Gouet, PH. (1982). Kinetics of the establishment of gastro-intestinal microflora in the conventional new born rat. Annales de microbiologie 333B, 325-334.

BRYANT, M. P. (1972). Commentary on the Hungate technique for culture of anaerobic bacteria. American Journal of Clinical Nutrition 25, 1324-1328.

Bryant, M. P. \& BuRkey, L. A. (1953). Cultural methods and some characteristics of some of the more numerous groups of bacteria in the bovine rumen. Journal of Dairy Science 36, 205-217.

BRYANT, M. P. \& SMall, N. (1960). Observations on the ruminal microorganisms of isolated and inoculated calves. Journal of Dairy Science 43, 654-667.

Bryant, M. P., Small, N., Bouma, C. \& Robinson, 1. M. (1958). Studies of the composition of the ruminal flora and fauna of young calves. Journal of Dairy Science 41, 1747-1767.

Buchanan, R. E. \& Gibbons, N. E. (editors) (1974). Bergey's Manual of Determinative Bacteriology, 8th edn. Baltimore: Williams \& Wilkins.

Cheng, K. J., IR VIN, R. T. \& Costerton, J . W. (1981). Autochthonous and pathogenic colonization of animal tissues by bacteria. Canadian Journal of Microbiology 27, 461-490.

DEHORITY, B. A. (1963). Isolation and characterization of several cellulolytic bacteria from in vitro rumen fermentation. Journal of Dairy Science 46, 217-222.

DEHORITY, B. A. \& GRUBB, J. A. (1981). Bacterial population adherent to the epithelium on the roof of the dorsal rumen of sheep. Applied and Environmental Microbiology 41, 1424-1427.

Ducluzeau, R. (1983). Implantation and development of the gut flora in the newborn animal. Annales de recherches vétérinaires 14, 354-359.

EADIE, J. M. (1962). The development of rumen microbial populations in lambs and calves under various conditions of management. Journal of General Microbiology 29, 563-578.

Fonty, G., Gouet, Ph., Jouany, J. P. \& Senaud, J. (1983). Ecological factors determining the establishment of cellulolytic bacteria and protozoa in the rumen of meroxenic lambs. Journal of General Microbiology 129, 213-223.

Gouet, Ph. \& Fonty, G. (1979). Changes in the digestive microflora of holoxenic rabbits from birth until adulthood. Annales de biologie animale, biochimie, biophysique 19, 553-566.

Hespell, R. B. \& BRYANT, M. P. (1979). Efficiency of rumen microbial growth: influence of some theoretical and experimental factors on $Y_{\text {ATP. Journal of }}$ Animal Science 49, 1640-1659.
Hobson, P. N. (1969). Rumen bacteria. Methods in Microbiology 3B, 133-149.

Holdeman, L. V. \& MoORE, W. E. C. (1972). Anaerobe Laboratory Manual. Blacksburg, Virginia: VPI Anaerobe Laboratory.

JAYNE-WiLliams, D. J. (1979). The bacterial flora of the rumen of healthy and bloating calves. Journal of Applied Bacteriology 47, 271-283.

JOBLIN, K. N. (1981). Isolation, enumeration and maintenance of rumen anaerobic fungi in roll tubes. Applied and Environmental Microbiology 42, 11191122.

JounNY, J. P. (1982). Volatile fatty acid and alcohol determination in digestive contents, silage juices, bacterial cultures and anaerobic fermentor content. Sciences des aliments 2, 131-144.

LengemanN, F. W. \& Allen, N. N. (1959). Development of rumen function in the dairy calf. II. Effect of diet upon characteristics of the rumen flora and fauna of young calves. Journal of Dairy Science $\mathbf{4 2}$, 1171-1181.

Mackay, E. S. M. \& Oxford, A. E. (1954). Some facultatively anaerobic Gram-negative rods from the rumen of the calf and the sheep. Journal of General Microbiology 11, 472-474.

MANN, S. O. (1963). Some observations on the airborne dissemination of rumen bacteria. Journal of General Microbiology 33, 9-10.

MANN, S. O. \& OXFORD, A. E. (1954). Studies on some presumptive lactobacilli isolated from the rumens of young calves. Journal of General Microbiology 11, 8390.

ManN, S. O. \& Oxford, A. E. (1955). Relationship between viable saccharolytic bacteria in the rumen and abomasum of the young calf and kid. Journal of General Microbiology 12, 140-146.

MORISHITA, Y. \& MIYAKI, K. (1979). Effect of age and starvation on the gastrointestinal microflora and the heat resistance of fecal bacteria in rat. Microbiology and Immunology 23, 455-470.

Mueller, R. E., Asplund, J. M. \& IAnnotti, E. L. $(1984 a)$. Successive changes in the epimural bacterial community of young lambs as revealed by scanning electron microscopy. Applied and Environmental Microbiology 47, 715-723.

Mueller, R. E., IANnotti, E. L. \& Asplund, J. M. $(1984 b)$. Isolation and identification of adherent epimural bacteria during succession in young lambs. Applied and Environmental Microbiology 47, 724-730.

ORPIN, C. G. (1981). Fungi in ruminant degradation. In Degradation of Plant Material (Agricultural Science Seminar), pp. 37-46. London: Agricultural Research Council.

ORPIN, C. G. (1984). The role of ciliate protozoa and fungi in the rumen digestion of plant cell walls Animal Feed Science and Technology 10, 121-143.

Pounden, W. D. \& HibBs, J. W. (1948a). The influence of the ration and rumen inoculation on the establishment of certain micro-organisms in the rumen of young calves. Journal of Dairy Science 31, 1041-1050.

Pounden, W. D. \& HibBs, J. W. (1948b). The influence of the ratio of grain to hay in the ration of dairy calves on certain micro-organisms. Journal of Dairy Science 31, 1051-1059. 
Raibaud, P., Dickinson, A., Sacquet, E., Charlier, H. \& Moceuot, G. (1966a). La microflore du tube digestif du rat. I. Techniques d'études et milieux de culture proposés. Annales de l'Institut Pasteur 110, 568-590.

Raibaud, P., Dickinson, A., Sacquet, E., Charlier, H. \& MocQuot, G. $(1966 b)$. La microflore du tube digestif du rat. II. Dénombrements de différents genres microbiens dans l'estomac et l'intestin de rats conventionnels. Variations quantitatives et en fonction de l'âge. Annales de l'Institut Pasteur 111, 193210 .
Smith, P. H. \& Hungate, R. E. (1958). Isolation and characterization of Methanobacterium ruminantium n. sp. Journal of Bacteriology 75, 713-718.

Wilkins, T. D., Walker, C. B. \& Moore, W. E. C. (1975). Micromethod for identification of anaerobic bacteria : design and operation of apparatus. Applied Microbiology 30, 831-837.

ZioleCKI, A. \& BRIGgs, C. A. E. (1961). The microflora of the rumen of the young calf. II. Source, nature and development. Journal of Applied Bacteriology 24, 148-163. 